\title{
Presentation Course Design of Animal Disease Based on Teaching Basic Skills Competition
}

\author{
Sanping Bu
}

Baying Guo Leng Vocational and Technical College, Xinjiang, Korla, China, 841000

\section{Keywords: Animal Disease, Presentation Course Design}

\begin{abstract}
Animal disease" is a certificate of animal husbandry and veterinary professional courses with a strong practical practice, this paper from the curriculum development, positioning, curriculum objectives, curriculum design, teaching design and other aspects of teaching based on basic skills contest design in improving the quality of animal disease teaching.
\end{abstract}

\section{Introduction}

In order to carry out the spirit of the work conference of the Party Committee of the Xinjiang Uygur Autonomous Region, the teachers of vocational colleges in Xinjiang Uygur Autonomous Region are aiming to improve the basic skills of teachers' teaching in our district and to promote teachers to improve their basic teaching skills and basic skill contest.

The development and breakthrough of higher vocational education and teaching theory provide the necessary theoretical basis for the development and reform of teaching methods. In particular, Professor Jiang Daoyuan's system-based curriculum development and design theory is important to the curriculum reform of higher vocational education guidance [1-3]. In order to adapt to the teaching needs as soon as possible, this group has carried out the overall design of the systematic course based on the course of animal disease, and has maintained the advanced nature and practicability of the course teaching.

I am based on teaching basic skills contest under the "animal disease" course lectures, to talk design.

\section{Course Development}

The course is the development of animal husbandry and veterinary professional teaching and research teacher with the school-enterprise cooperation Bazhou dairy, Ruiyuan dairy, Sanyu dairy, county and county veterinary station experts to discuss professional career, to sum up the typical task, the formation of action areas and build a course system based on the work process, and then jointly develop curriculum standards to determine the teaching content of this course.

\section{Course Orientation}

According to animal husbandry and veterinary professional personnel training objectives and requirements, for animal disease prevention and control of the core competencies, set up the professional core class. In the follow-up courses play a bridge role, training disease diagnosis ability, disease prevention and control ability, epidemic report and dead animal management capacity. Support the animal disease prevention staff professional ability and professional quality. 


\section{Course Relationship}

Before studying this course, students first studied animal anatomy, animal microbiology, animal husbandry, veterinary basis, parallel courses have animal clinical treatment technology, follow-up courses are cattle and bovine disease prevention and control, sheep and sheep disease prevention and control, poultry and poultry disease prevention and control, special animal production technology.

Through the course to learn students can get animal disease prevention and control, animal quarantine inspector certificate, but also the village animal epidemic prevention staff required application of technical courses to meet business needs to achieve certificates.

\section{Course Objectives}

Through the study of this course, students have the ability to set the animal infectious disease immunization program; have the common disease diagnosis and treatment, prevention, elimination ability; have the common disease laboratory diagnostic ability. Master the occurrence of animal disease, development, epidemic law; master the diagnosis of disease; control of disease prevention and control measures. Cultivate a good professional ethics, professionalism, teamwork awareness, pay close attention to Xinjiang, the latest animal disease and in the production continue to acquire new knowledge and new skills.

\section{Course Design}

Course design concept: based on job analysis ability, the formation of the work process based on the curriculum system, and the curriculum project, task, highlight the practical ability to train, to achieve "do teaching, do secondary school." According to the law of students' cognition, according to the law of occupational growth, the project of animal disease teaching and the task of work are determined, and the actual process of enterprise production is simulated.

Content Selection. This course is based on the common skills of animal disease, with reference to the "animal disease prevention and control" professional certificate set teaching content, from easy to difficult, from simple to complex, from a single skill to the comprehensive ability to show students to master animal disease prevention and control technology.

Content Organization. According to the curriculum development and analysis of typical work process tasks, animal epidemic disease developed four projects, 20 typical tasks, including the basic skills of animal disease, the diagnosis and prevention of Brucellosis, the diagnosis and prevention of tuberculosis, foot and mouth disease diagnosis and prevention and control for the teaching focus; animal epidemic prevention plan development, brucellosis quarantine, tuberculosis quarantine, avian flu diagnosis difficult teaching.

Teaching Materials. This course is selected from the 21st century Department of Agriculture Vocational Education Planning Materials, Zhang Hongwei, Dong Yongsen editor of the "animal disease", in January 2014 by the China Agricultural Publishing House; reference materials are animal disease, animal husbandry and veterinary comprehensive skills. According to the professional teaching standards, combined with the requirements of animal disease prevention staff positions, the content of the curriculum to integrate the real task for the knowledge of the situation embedded in which to start teaching and learning.

Content Performance. For the students to prepare a wealth of teaching materials, teaching cases are used in the work of the epidemic cases; for the work of the actual operation of the case to prepare courseware; the problem library resources are rich theoretical questions and training project 
questions; training internship projects are teaching training, spring and autumn epidemic prevention practice and graduation practice; for students to provide a large number of reference materials and reference materials, and related professional website.

Content Performance. For students to prepare a single task list, teacher evaluation form, student self-assessment and group assessment, the project evaluation criteria and curriculum lesson plans.

\section{Teaching Design}

Teaching design concept: the ability to cultivate career opportunities for the first - focus on quality; teaching objectives around the job requirements - school - enterprise docking; work process - task driven.

Analysis of Learning Situation. This course is offered in the third semester. Students have mastered the basic knowledge of animal husbandry and veterinary profession, have a certain practical ability, eager to learn to master professional skills, for learning, we "student-oriented, teacher-led" principle guiding the cause of the situation. At the same time to encourage students to spare time to farming enterprises, veterinary stations and more practical exercise.

Teaching Model. Teaching model: the use of consulting, decision-making, planning, implementation, inspection, evaluation six-step method. Students to carry out epidemic disease case analysis - to determine the prevention and control programs - to develop diagnostic methods - to choose prevention and control programs - disease diagnosis - disease treatment - disease prevention and control - prevention and treatment effect. Through the action-oriented teaching, the main role of students highlights the teaching effect improved significantly.

For example, in each learning situation, to "work tasks" as the center to build the internal structure of learning context, based on the work process to arrange knowledge points. According to the actual teaching needs, set up different sub-context, each learning sub-context, is a typical task, knowledge of the order is in accordance with the process of animal disease prevention and control of six steps [4]. According to this idea, the "animal disease" a learning situation knowledge of the order, see Table 1.

Table 1 Sequence of knowledge points in foot and mouth disease control technology

\begin{tabular}{|c|c|c|c|c|c|c|c|}
\hline \multirow{2}{*}{$\begin{array}{l}\text { Learning } \\
\text { Situation }\end{array}$} & \multirow{2}{*}{$\begin{array}{l}\text { Sub-Context } \\
\text { Carrier }\end{array}$} & \multicolumn{6}{|c|}{ Work Process } \\
\hline & & Advisory & $\begin{array}{l}\text { Decision } \\
\text { Making }\end{array}$ & Plan & Implementation & Examination & Evaluation \\
\hline $\begin{array}{l}\text { Prevention } \\
\text { and } \\
\text { control } \\
\text { technology } \\
\text { of cattle }\end{array}$ & $\begin{array}{l}\text { Prevention } \\
\text { and } \\
\text { treatment of } \\
\text { foot and } \\
\text { mouth } \\
\text { disease }\end{array}$ & $\begin{array}{l}\text { Investigate } \\
\text { the onset } \\
\text { time, place, } \\
\text { scope, } \\
\text { morbidity, } \\
\text { mortality, } \\
\text { animal } \\
\text { immune } \\
\text { status, etc .; } \\
\text { clinical } \\
\text { symptoms, } \\
\text { septal } \\
\text { pathological }\end{array}$ & $\begin{array}{l}\text { According to } \\
\text { the clinical } \\
\text { symptoms of } \\
\text { foot and } \\
\text { mouth } \\
\text { disease, the } \\
\text { characteristics } \\
\text { of the initial } \\
\text { diagnosis of } \\
\text { reverse } \\
\text { transcription; } \\
\text { reverse } \\
\text { transcription }\end{array}$ & $\begin{array}{l}\text { To develop } \\
\text { isolation, } \\
\text { blockade, } \\
\text { disinfection } \\
\text { and } \\
\text { immediate } \\
\text { vaccination } \\
\text { program; } \\
\text { incidence } \\
\text { of cattle } \\
\text { treatment } \\
\text { program. }\end{array}$ & $\begin{array}{l}\text { The incidence } \\
\text { of cattle farms } \\
\text { is blocked, } \\
\text { disinfected, } \\
\text { assuming } \\
\text { healthy cattle } \\
\text { are vaccinated } \\
\text { urgently. }\end{array}$ & $\begin{array}{l}\text { Disease } \\
\text { control } \\
\text { effect check, } \\
\text { sick animal } \\
\text { treatment } \\
\text { effect check. }\end{array}$ & $\begin{array}{l}\text { Evaluate the } \\
\text { results, } \\
\text { whether the } \\
\text { measures are } \\
\text { appropriate, } \\
\text { sum up } \\
\text { lessons } \\
\text { learned. }\end{array}$ \\
\hline
\end{tabular}




\begin{tabular}{|l|l|l|l|l|l|l|}
\hline & $\begin{array}{l}\text { changes } \\
\text { observed } \\
\text { records. }\end{array}$ & $\begin{array}{l}\text { polymerase } \\
\text { chain reaction } \\
\text { (RT-PCR) and } \\
\text { other } \\
\text { laboratory } \\
\text { tests for } \\
\text { diagnosis }\end{array}$ & & & & \\
& & & & & \\
\hline
\end{tabular}

Teaching Methods. According to the different content of the course, the use of different teaching methods, to take case teaching methods (such as the incidence of livestock on-site clinical examination, to make a diagnosis, and to develop reasonable prevention and control measures); task-driven teaching method (such as the guidance of business mentors (Such as the development of emergency vaccination programs for infectious diseases in farms); role-playing teaching method (if you are a village-level animal), the program design method Disease prevention and control staff, the village farmers cattle, sheep, how to prevent and control);

Teaching Methods. Make full use of modern multimedia technology teaching, fully demonstrate the teaching objectives. Simulation teaching - students will observe the pathological changes, clinical features, body temperature, breathing, pulse and other related indicators input to the simulation software, will automatically diagnose the disease name for students to refer to. Site teaching, improve the practice of operational skills and experience the workplace atmosphere.

\section{Teaching Team}

"Animal disease" course for many years with the industry, business experts and front-line staff to carry out curriculum construction, has established a "school-enterprise cooperation, special combination" of the double teacher teaching team. At present, there are 11 teachers in the course group, including 8 full-time teachers in the hospital, and 3 part-time teachers with rich experience in the production of the hospital. The curriculum construction embodies the characteristics of "combination of work and study" and "teaching, learning and integration" "The basic requirements of the faculty.

\section{Teaching Resources}

In-School Training. At present, our hospital animal husbandry and veterinary professional mainly multimedia simulation training room, electron microscope training room, animal anatomy training room, microbiology training room. The following is the training room equipment and students in the practice room practice photos.

Out of School Training. At present, animal husbandry and veterinary professional has been with the Bazhou dairy farms, Ruiyuan Dairy, San Yu dairy and other enterprises and more than 20 enterprises signed a training practice agreement for the students outside the training practice provides a solid training conditions.

\section{Teaching Evaluation}

Teaching evaluation uses "the combination of the results and the process, the combination of skills and quality, self-evaluation and his assessment of the combination of" way to evaluate.

Animal husbandry and veterinary professional qualification certificates are: animal disease prevention and control, animal quarantine inspectors, livestock breeding workers, the fifth semester to carry out vocational skills identification work, student certification rate of $96 \%$ or more. 


\section{Course Effect}

Since 2010, animal husbandry and veterinary professional students have participated in the autonomous region skills competition, and get excellent results, in 2015 higher vocational students Qi Wenan, Dali to participate in "chicken body seepage and sampling" project won the first Xinjiang, on behalf of Xinjiang Group participated in the national skills contest and won the national skills contest third prize good results.

This course is based on the work process of curriculum development and construction, through systematic development and construction, to achieve work and study, one by one, highlighting the practical, open, professional characteristics of vocational education.

\section{Teaching Reflection}

This course is closely related to the production of livestock and poultry. In the teaching process, students contact the reality, the discussion is more enthusiastic. Especially for the current zoonotic disease, students put forward a lot of programs. Fully mobilize the students love the community, from the community, to the community to the enthusiasm. Pull into the control of disease and the distance between students and improve students' sense of social responsibility.

Reflect the teaching content, optimize the integration of teaching materials - textbook content lag, slow knowledge update, the development of regional characteristics of textbooks; reflect on school-enterprise cooperation, strengthen the school-enterprise joint - in business, students, schools tripartite benefit principle, Joint; to strengthen the vocational, undergraduate convergence - through the undergraduate examinations and other ways to achieve higher vocational, undergraduate mutual convergence.

\section{References}

[1] Jiang Daoyuan. On the development of systematic course of higher vocational education work [J]. Journal of Xuzhou Construction Vocational and Technical College, 2010, 10 (1): 1-6.

[2] Jiang Daoyuan. Contemporary German vocational education mainstream teaching thought: theory, practice and innovation [M]. Beijing: Tsinghua University Press, 2007.

[3] Jiang Daoyuan. On the Systematic Design of Higher Vocational Education Curriculum - On the Development of Systematic Course of Work Process[J]. China Higher Education Research, 2009, (4): 66-70.

[4] Zhu Xiaofu, Wu Xujin, Xu Degan. "Development and design of animal disease prevention and control technology" based on systematic process of work[J]. Shanghai Animal Husbandry and Veterinary Communication, 2013, (1): 67. 